\title{
Microbial Flora of Corneal Ulcer and their Drugs Sensitivity.
}

Meena Kunwarl, Rishi Kant Adhikari², Deep Bahadur Karki².

\section{${ }^{1}$ Department of Ophthalmology, Armed Police Force Hospital. ${ }^{2}$ Department of Ophthalmology, Nepal Eye Hospital.}

\section{ABSTRACT}

Introduction: Corneal ulcer is a leading cause of ocular morbidity and blindness worldwide. Knowledge of the common organism causing corneal ulcers and the sensitivity of the bacteria will help formulate the first line of treatment which would have relatively high percentage of success even in areas devoid of diagnostic facilities. The main objective of this study was to find out commonest organisms that cause corneal ulcers and to determine their antimicrobial susceptibility.

Methods: This was a prospective study of 55 consecutive cases of corneal ulcers. Patients who had congenital abnormality of cornea, uncooperative patient not allowing to do corneal scrapping, patient with suspected or confirmed viral keratitis, Patient with corneal ulcer with HIV positive and all non-infective corneal ulcers were excluded from the study.

Results: Of 55 cases enrolled in this study microorganisms were grown from 31 (56\%) cases. Of 31 growth positive cases, $17(54.8 \%)$ showed pure bacterial growth, $13(41.9 \%)$ cases showed pure fungal growth and in only 1 (3.2\%) case there was mixed (bacteria and fungus) growth. Among the tested antibiotic, sensitivity of Ciprofloxacin and Gentamicinewas $100 \%$ and that of Ceftriaxone was nearly $94 \%$. Almost $20 \%$ bacteria were resistant to Chloramphenicol. Sensitivity of newer quinolone (Ofloxacine) was also not very high, having more than $20 \%$ bacteria resistant to it.

Conclusions: The commonest organism responsible for bacterial keratitis was strepto. Pneumonia. Ciprofloxacin and Gentamicin were the most sensitive antibiotics.

Keywords: corneal ulcer, blindness, sensitivity, antibiotics.

\section{INTRODUCTION}

Corneal ulcer is a leading cause of ocular morbidity and blindness worldwide ${ }^{1}$. In some developing countries of the tropics and subtropics, corneal infections are the second commonest cause of blindness after unoperated cataract ${ }^{2}$. Nepal, being a developing country, most of her population depend on agriculture, so they are more exposed to agricultural trauma during their work. Moreover, lack of knowledge and poor health facility are the reasons for trivial ocular trauma leading to corneal ulcers. Knowledge of the common organism causing corneal ulcers and the sensitivity of the bacteria will help formulate the first line of treatment which would have relatively high percentage of success even in areas devoid of diagnostic facilities. In Nepal with limited static health institutions and fewer medical staffs this would facilitate institution of early and appropriate therapy. The main objective of this study is to find out commonest organism that causes corneal ulcers and to determine their antimicrobial susceptibility.

\section{METHODS}

This prospective study was conducted at Nepal Eye Hospital from over a period of one year. A total of 55 patients who were admitted in Nepal Eye Hospital were enrolled in this study. All the patients with corneal ulcer with or without hypopyon of all age group were included. Patients who had congenital abnormality of cornea, uncooperative patient not allowing to do corneal scrapping, patient with suspected or confirmed

\section{Correspondence:}

Dr. Meena Kunwar

Department of Ophthalmology, Armed Police Force Hospital,

Kathmandu, Nepal.

Email: drmeenakunwar@gmail.com 
MJSBH January-June 2013|Vol 12| Issue 1

viral keratitis, patient with corneal ulcer with HIV positive and all non-infective corneal ulcers were excluded from the study. Data were analyzed using the SPSS v13 program.

All patients underwent corneal scraping. In patient, who have already used antibiotics, antibiotics were stopped for 12-24 hours and scraping was done. After instillation of topical anesthetics, a speculum was placed for better exposure of cornea and to decrease the mobility of lids. Then with the help of Kimura spatula or No. 15 surgical blade, the ulcer was scraped from the margin and base. The scraped materials were subjected to Gram stain, $\mathrm{KOH}$, and inoculated in the four different culture media ( Blood agar, Chocolate agar, Mc Conkey agar and Sabouraud dextrose agar). All the media were incubated at room temperature except Sabouraud dextrose agar, which was incubated at 27 degree centigrade. After the scraping of the ulcer patients were treated with broad-spectrum antibiotic or antifungal depending on history and ulcer pattern. The treatment was changed later according to the sensitivity report.

\section{Table 1. Demographic parameters}

\begin{tabular}{|ll|}
\hline \multicolumn{1}{|c|}{ Mge } & \\
Mean & $55 \pm 20.04$ \\
Range & $10-90$ Years \\
\hline $\begin{array}{l}\text { Age group (Years) } \\
\text { Less than 20 } \\
21-40 \text { years }\end{array}$ & $6(10.9 \%)$ \\
$41-60$ years & $15(27.3 \%)$ \\
More than 60 & $18(32.7 \%)$ \\
Sex & $16(29.1 \%)$ \\
Male & $30(55 \%)$ \\
Female & $25(45 \%)$ \\
Occupation & \\
Farmer & $30(55 \%)$ \\
Housewives & $11(20 \%)$ \\
Students & $6(10.9 \%)$ \\
Laborers & $1(1.2 \%)$ \\
Others & $7(12.7 \%)$ \\
\hline Literacy & \\
Illiterate & $29(53 \%)$ \\
School literate & $17(31 \%)$ \\
Literate & $9(16 \%)$ \\
\hline
\end{tabular}

\section{RESULTS}

During the study period a total of 95 patients were admitted in septic ward of Nepal Eye Hospital with the diagnosis of corneal ulcers. 40 patients were excluded from the study because of various reasons like viral keratitis, uncooperative patients and non-infective keratitis. Remaining 55 patients, who fulfilled the inclusion criteria, were enrolled in the study and their demographic data are shown in Table 1.

The commonest organism responsible for bacterial keratitis was Strepto. Pneumoniae (29.41\%) and was followed by Staphylococcus Aureus (11.76) (Table 2). From 31 culture positive cases, 13 (41.9\%) were fungus. The most common fungus was Candida Albicans (38.46\%), and was followed by Aspergillus Species (30.76\%) (Table3). Among the tested antibiotic, sensitivity of Ciprofloxacin and Gentamycine was $100 \%$ and that of Ceftriaxone was nearly $94 \%$. Almost $20 \%$ bacteria were resistant to Chloramphenicol. Sensitivity of newer quinolone (Ofloxacine) was also not very high, having more than $20 \%$ bacteria resistant to it (Table 4).

Table 2. Pattern of Bacterial growth

\begin{tabular}{|lcc|}
\hline Bacteria & Frequency & Percent \\
Strepto. Pneumoniae & 5 & $29.41 \%$ \\
\hline Staphylococcus Aureus & 2 & $11.76 \%$ \\
\hline Pseudomonas Aeruginosa & 2 & $11.76 \%$ \\
\hline Klebsiella species & 2 & $11.76 \%$ \\
\hline Streptococcus Viridence & 1 & $5.88 \%$ \\
\hline Strepto. Pyogenes gr A & 1 & $5.88 \%$ \\
\hline Strepto. Pyogenes & 1 & $5.88 \%$ \\
\hline Hemophilus species & 1 & $5.88 \%$ \\
\hline Aeromonas species & 1 & $5.88 \%$ \\
\hline Acinetobacter species & 1 & $5.88 \%$ \\
\hline \multicolumn{1}{c}{ Total } & 17 & $100 \%$ \\
\hline
\end{tabular}

Table 3. Pattern of Fungal growth

\begin{tabular}{|lcc|}
\hline Fungus & Frequency & Percent \\
Candida Albicans & 5 & $38.46 \%$ \\
\hline Aspergillus Species & 4 & $30.76 \%$ \\
\hline Carbularis Species & 1 & $7.69 \%$ \\
\hline Epidermophyton Species & 1 & $7.69 \%$ \\
Microsporum Species & 1 & $7.69 \%$ \\
\hline Rhizopus Species & 1 & $7.69 \%$ \\
\hline
\end{tabular}

DISCUSSION 
MJSBH January-June 2013|Vol 12| Issue 1

Table 4. Drug sensitivity pattern

\begin{tabular}{|c|c|c|c|c|c|c|c|}
\hline \multirow[t]{2}{*}{ Antibiotics } & \multirow[t]{2}{*}{ tested } & \multicolumn{2}{|c|}{ Sensitive } & \multicolumn{2}{|c|}{ Partial sensitive } & \multicolumn{2}{|r|}{ Resistant } \\
\hline & & No & $\%$ & No & $\%$ & No & $\%$ \\
\hline Ciprofloxacin & 14 & 14 & $100 \%$ & 0 & $0 \%$ & 0 & $0 \%$ \\
\hline Gentamycine & 8 & 8 & $100 \%$ & 0 & $0 \%$ & 0 & $0 \%$ \\
\hline Chloramphenicol & 16 & 12 & $75 \%$ & 1 & $6.25 \%$ & 3 & $18.75 \%$ \\
\hline Ceftriaxone & 16 & 15 & $93.75 \%$ & 0 & $0 \%$ & 1 & $6.25 \%$ \\
\hline Ofloxacine & 9 & 7 & $77.7 \%$ & 0 & $0 \%$ & 2 & $22.3 \%$ \\
\hline Cotrimoxazole & 14 & 7 & $50 \%$ & 0 & $0 \%$ & 7 & $50 \%$ \\
\hline Penicillin & 12 & 9 & $75 \%$ & 1 & $8.33 \%$ & 2 & $16.66 \%$ \\
\hline Ampicillin & 11 & 7 & $63.63 \%$ & 1 & $9.09 \%$ & 3 & $27.27 \%$ \\
\hline
\end{tabular}

In view of frequent reports of changing pattern of susceptibility among the bacteria, testing of isolates for their sensitivity to various antimicrobial drugs is necessary for selection of appropriate antibiotics.

Majority of the patient (54.5\%) in our study were farmer, followed by housewives (20\%), students $(10.9 \%)$, and laborers (1.2\%) (Table1). Similar distributions were mentioned by M .P. Upadhya ${ }^{3}$, Bashir. $\mathrm{G}^{4}$, Deshpande S.D ${ }^{5}$. During literature review we noticed that, majority of the patients were contact lenses users in developed countries $^{6,7}$. Farmers were not mentioned in their literatures. Farming is the most common occupation in our country and only professionals do farming with adequate protection and equipments in developed countries. Lack of protection and awareness of injury during farming may be the cause of high incidence of corneal ulcers in farmers in our part of the world.

Trauma was the most frequent predisposing factor affecting 35 out of 55 cases, a percent prevalence of $64 \%$. All cases of injury were accidental. We did not encounter cases of corneal ulcers following surgical injury though they have been reported by other studies 8,9 . Trauma was prevalent predisposing factor in many studies, MP Upadhyay ${ }^{3}$ (52.8\%), Basak SK ${ }^{10}$ (82.9\%), Shrinivasan $\mathrm{M}^{11}(65.4 \%)$. Vegetative matters were the most frequently identified traumatic agents $28(80 \%)$ out of 35 traumatic cases (Figure 1). This is easily explained by deployment of large section of Nepalese population in agriculture. The corneal ulcers in Nepal are an agriculture dependant occupational hazard is further supplied by the fact that paddy, which is the principal crop, accounted for almost one third (31.4\%) of all injury cases. In other injury cases, maize accounted for $17.1 \%$, leaf $17.1 \%$ and wood stick for $11.4 \%$ of all trauma cases. During the study period we had no cases of contact lenses related corneal ulcers which was considered to be one of the commonest causative factor in developed countries ${ }^{12-16}$. The reason behind this is the rare use of contact lenses in our country. Very few people in Nepal use contact lenses, where as it is used frequently in developed countries. The other reason may be the small sample size of the study.

According to various studies the incidence of culture positive cases vary from $45 \%$ to $90 \% 3,10-12,16,17,18$. In a study from $\mathrm{Nepal}^{3}$ which was published in 1988 organisms were grown from $80 \%$ of the cases. In another study from Nepal ${ }^{12}$, the growth percentage was only $45.3 \%$. In our study the growth percentage was $56 \%$. Wide variation in culture positivity may be because of antibiotics use prior to presenting in hospital.

Among 31 culture positive cases 17(54.8\%) were bacteria, $13(41.9 \%)$ were fungus and we had only 1 cases (3.2\%) of mixed growth. Similar growth incidence was reported by Dunlop AA $^{19}$, Srinivasan ${ }^{11}$ and Williams $\mathrm{G}^{20}$. During literature review we noticed wide range of bacterial and fungal growth ${ }^{3,10,21,16}$. This variation may be because of the various geographical and environmental conditions in which the studies were conducted.

Bacterial spectrum of our study was similar to most of the previously reported series 3,11,22,21. Dunlop AA et $\mathrm{a}^{19}$ reported pseudomonas as the most frequent bacterial pathogen. Whereas others have reported $\mathrm{d}^{6,9,10,23}$ 
MJSBH January-June 2013|Vol 12| Issue 1

Staph. Aureus as the commonest isolate. In our study the commonest isolate was Streptococcus Pneumoniae, which accounted for $29.41 \%$ of all bacterial isolates. Pseudomonas aeruginosa and klebsiella species were found to be the predominant gram negative isolates accounting for $28.55 \%$ among the isolates.

Various studies ${ }^{3,12,23,24}$ have mentioned the higher sensitivity to ciprofloxacin and remained same in our study also. Very few studies ${ }^{7}$ have mentioned about the Gentamycine, but we found $100 \%$ sensitivity to Gentamycine. We think that ciprofloxacin and Gentamycine must be considered as the choice of drug for bacterial corneal ulcer.

\section{CONCLUSION}

The commonest organism responsible for bacterial keratitis was Strepto. Pneumoniae (29.41\%). Among fungal growth Candida Albicans was the commonest fungus. Among the tested antibiotics sensitivity of Ciprofloxacin and Gentamycine was $100 \%$ and that of Ceftriaxone was nearly $94 \%$.

\section{REFERENCES}

1. Kunimoto DY, Sharma S, Garg P, Gopinath U, Miller D, Rao GN. Corneal ulceration in the elderly in Hyderabad, south India. Br J Ophthalmol. 2000;84:54-9.

2. Leck AK, Thomas PA, Hagan M, Kalimurthy J, Ackuku E, John $M$, et al. Etiology of suppurative corneal ulcers in Ghana and south India, and epidemiology of fungal keratitis. $\mathrm{Br} J$ Ophthalmol. 2002;86:1211-5.

3. Upadhyay MP, Karmacharya PC, Koirala SK. Epidemiology and Microbiology of corneal suppuration, Tribhuvan University, Institute of Medical Science, Kathmandu, Nepal, 1998.

4. Bashir G, Shah A, Thokar MA, Rashid S, Shakeel S. Bacterial and fungal profile of corneal ulcers--a prospective study. Indian J Pathol Microbiol. 2005;48:273-7.

5. Deshpande SD, Koppikar GV. A study of mycotic keratitis in Mumbai. Indian J Pathol Microbiol. 1999;42:81-7.

6. Neumann $M$, Sjostrand $J$. Central microbial keratitis in a Swedish city population. A three-year prospective study in Gothenburg. Acta Ophthalmol (Copenh). 1993;71:160-4.

7. Tan DT, Lee CP, Lim AS. Corneal ulcers in two institutions in Singapore: analysis of causative factors, organisms and antibiotic resistance.Ann Acad Med Singapore. 1995, 24:823-9.

8. Kunimoto DY, Sharma S, Garg P,Gopinath U, Miller D, Rao GN. Corneal ulceration in the elderly in Hyderabad, south India. Br J Ophthalmol. 2000;84:54-9.

9. Cheung J, Slomovic AR. Microbial etiology and predisposing factors among patients hospitalized for corneal ulceration.
Can J Ophthalmol. 1995; 30:251-5.

10. Basak SK, Basak S, Mohanta A, Bhowmick A. Epidemiological and microbiological diagnosis of suppurative keratitis in Gangetic West Bengal, eastern India. Indian J Ophthalmol. 2005; $53: 17-22$.

11. Srinivasan M, Gonzales CA, George C,Cevallos V, Mascarenhas $J M$, Asokan B, et al. Epidemiology and etiological diagnoses of corneal ulceration in Madurai, south India. $\mathrm{Br}$ J Ophthalmol. 1997;81:965-71.

12. Neumann M, Sjostrand J. Central microbial keratitis in a Swedish city population. A three-year prospective study in Gothenburg. Acta Ophthalmol (Copenh). 1993;71:160-4.

13. Leck AK, Thomas PA, Hagan M, Kaliamurthy J, Ackuaka E, John M, et al. Aetiology of suppurative corneal ulcers in Ghana and south India, and epidemiology of fungal keratitis. Br J Ophthalmol. 2002;86:1211-15.

14. Bourcier T, Thomas F, Borderie V, Chaumeil C, Laroche L. Bacterial keratitis: predisposing factors, clinical and microbiological review of 300 cases. Br J Ophthalmol. 2003;87:834-8

15. Rosa RH, Miller D, Alfonso EC. The changing spectrum of fungal keratitis in south Florida. Ophthalmology. 1994;101:1005-13

16. Tanure MA, Cohen EJ, Sudesh S,Rapuano CJ, Laibson PR. Spectrum of fungal keratitis at Wills Eye Hospital Philadelphia, Pennsylvania. Cornea. 2000;19:307-12.

17. Williams G, McClellan K, Billson F. Suppurative keratitis in rural Bangladesh: the value of gram stain in planning management. Int Ophthalmol. 1991;15:131-5.

18. Hagan M, Wright E, Newman M, Dolin P, Johnson G. Causes of suppurative keratitis in Ghana. Br $J$ Ophthalmol. 1995;79:1024-8.

19. Dunlop AA, Wright ED, Howlader SA, Nazrul I, Husain R, McClellan $K$, et al. Suppurative corneal ulceration in Bangladesh. Aus NZ J Ophthalmol. 1994;22:105-10.

20. Williams G, Billson F, Husain R,Howlader SA, Islam N, McClellan K. Microbiological diagnosis of suppurative keratitis in Bangladesh. Br J Ophthalmol. 1987;71:315-21.

21. Bharathi MJ, Ramakrishnan R, Vasu S, Meenakshi, Palaniappan R. Aetiological diagnosis of microbial keratitis in South India - A study of 1618 cases. Indian Journal of Ophthalmology. 2002;20:19-24.

22. Gonzales CA, Srinivasan M, Whitcher JP, Smolin G. Incidence of corneal ulceration in Madurai District, south India. Ophthalmic Epidemiol. 1996;3:159-66.

23. Chaudhary A, Singh TSK, Lalchandani S, Kumar S, Shrestha $S P$, Sekhri R. Corneal ulceration and microbial keratitis in Pokhara Nepal. Journal of the Nepal medical association. 1999;38:18-22.

24. Duggirala A, Joseph J, Sharma S, Nutheti R, Garg P, Das T. Activity of newer fluoroquinolones against gram-positive and gram-negative bacteria isolated from ocular infections: An in vitro comparison. Indian Journal of Ophthalmology. $2007: 55: 15-19$

Medical Journal of $S$ hree Birendra Hospital 